\title{
The Impact of Service Quality and Institutional Image on the Satisfaction and Loyalty of Master of Management Students
}

\author{
Nursaid $^{1 *}$, Sapta Hadi Purnomo ${ }^{1}$, Nurul Qomariah ${ }^{1}$ \\ ${ }^{1}$ Universitas Muhammadiyah Jember, Jember, Indonesia \\ "Corresponding author. Email: nursaid@unmuhjember.ac.id
}

\begin{abstract}
This study aimed to determine the effect of service quality, image of the institution on the satisfaction and loyalty of master's degree in management at Universitas Muhammadiyah Jember. The study population was all graduate students in Management Universitas Muhammadiyah Jember, and 50 students of them were taken as samples. Validity and reliability tests are used to test questionnaires which were used as the research instruments. This study was analysed by using linear regression analysis of which influenced student satisfaction. The results of the study indicate that quality of service and institution's image to public affect student satisfaction. The quality of service and the institution's image affect student loyalty; in other words, student satisfaction does not affect student loyalty.

Keywords: service quality, image, student satisfaction, loyalty
\end{abstract}

\section{INTRODUCTION}

Today's marked global competition has impacted all business sectors. Reacting to this competition, a company is required to continuously improve its performance. This performance improvement is crucial so that the company can survive the amid intense competition. In addition to survival, this performance improvement also aims to provide satisfaction to customers or service users [1]. Customer satisfaction is the customer's feeling about the service he has received that exceeds his expectations. All business organizations engaged in services need to pay attention to customer satisfaction because satisfied customers will provide good information about the products and services they have used to prospective customers [2]. In addition to survive and win business competition in the era of globalization, business people are required to have precise strategies that may open more advantages over its competitors. The strategy must also be implemented in a planned, systematic and long-term manner. In implementing the strategy, it is necessary to measure performance, so that the success and influence of the implementation of the strategy for the company can be known.

Education is important to improve the quality of human resources. Higher education is expected to increase community knowledge and overcome any related problems. The government has provided an opportunity for private sectors in order to improve the quality of human resources through education. Based on the data from PDDIKTI, there are 122 state universities in Indonesia, and 3,128 tertiary institutions registered in the private universities (PD DIKTI, 2018). With the large number of universities in Indonesia, both state and private universities are in academic competition for gathering students to study in their universities. Moreover, with this enormous number of universities in Indonesia, what has to be considered is the quality of education obtained by the community. The university must continue to pay attention to the quality of education as it can help compete at the global level. What is needed for educational institutions both state and private tertiary institutions is how to provide educational services that can produce graduates who are ready to serve the community. The graduates of higher education that can be accepted by the community is one item that indicates educational institutions' ability to provide satisfaction to users of higher education services. People who are satisfied with the education services received will provide recommendations to other parties who need information about education. Seeing this, it is important for educational institutions to pay attention to customer's loyalty and satisfaction of education service users.

Customer loyalty is an act of customer repurchasing a product or service [3]. It is a consistent condition of the customer towards the products and services followed by a repeated purchase [4]. Dimensions of loyalty may include recommending products / services to others, informing good things about products that have been used, and telling the goodness and benefits of the product to others. Therefore, customer satisfaction is a contributing factor that can increase customer loyalty.

Customer satisfaction is a factor that can increase customer loyalty. Customer satisfaction is the level of one's feelings after comparing the performance with his/her expectations [5]. In other words, customer satisfaction is a condition in which desires, hopes and needs of customers can be met [6], therefore A service is considered satisfactory if the service can meet the needs and expectations of customers. Measuring customer satisfaction is an important element in providing better, more efficient and more effective services. Satisfied consumers will tend to recommend products they have used to others [4]. Satisfaction will also make customers inform about good things of the company to other 
service users. It can also make the relationship between customers and companies better established. Satisfied customers will also return to buy products that have been previously purchased. With a satisfied customer, customer loyalty will be formed.

Much research has been done on customer satisfaction and customer loyalty. Research on the relationship of customer loyalty with customer satisfaction has been done by researchers with a variety of different objects and produce different studies [3], [7]-[12]. The findings of the previous studies state that customer satisfaction can increase customer loyalty.

The next factor that can increase customer loyalty is service quality. Service quality is the nature of all products or services that can satisfy the needs of the community [2]. The relationship between service quality and customer loyalty is closely related. Quality of service is usually in the form of services that will be received by customers such as salon services, hospital services, shipping services, workshop services and so forth. Customers will immediately receive benefits from the services received. When the service fulfils the desires of customers, they will usually use the services. This is what causes customers to recommend these services to other customers. Research that links the relationship between service quality and customer loyalty has been done by several previous studies. Several studies [7], [8], [10], [13], [14], found that the quality of service can increase customer loyalty. While some others [12],[15] demonstrate no effect of service quality on loyalty.

Company image is also a factor that can increase customer loyalty. The company's image is a corporate identity that will be conveyed to the public [2]. Identity can be in the form of a logo, vision and mission of the company or the physical appearance of the company that will make a difference with other companies such as uniforms, office buildings, transportation equipment, brochures, banners, environment and so on [3]. The company must maintain its image so that the public service users remain loyal to the products / services offered. A company that has a good image will make its customers loyal to the products / services offered. Companies that can maintain its good image can increase the number of its customers. Much research has been done on company image and customer loyalty. The previous studies on this topic [10], [16]-[18] found that the company's image can make customers repeat purchases and recommend to other customers. However, [3], [19] [20], [21] state that there is no significant influence of the company's image on customer loyalty.

The next factor that needs attention from service providers is customer satisfaction. Customer satisfaction can be interpreted as customer emotions and reaction to feelings on the perceived difference between the performance and expectation about the service to be received [2]. Satisfaction occurs as after someone decided that the services received exceed his expectations [6]. Many factors can make customers feel satisfied. Factors allegedly can increase customer satisfaction, namely service quality and company image. Quality is a dynamic condition that affects products, services, people, processes and environments that meet or exceed expectations [5]. The quality of services provided to meet the needs and desires of consumers and the accuracy in delivering it will cause a match between the expectations and acceptance of consumers when marketing a product brand. In general, customers will assess not only the quality of products sold but also the services provided by the seller. The good quality of service provided by the service provider will certainly create a sense of comfort, which encourages customers to look for sellers and brands of the same product. Studies by [7], [9], [14], [10]-[12], [17]-[20], [22]-[24] argue that good service quality can increase customer satisfaction. While Qomariah states that service quality has no impact on customer satisfaction.

The company's image factor can also increase customer satisfaction. Company image can be illustrated by symbols, logo, vision and missions, uniforms, banners, brochures about the company providing the products / services [5]. The company is obliged to maintain its positive image to make its customers proud of using the company's products or services [6]. Research on company image and customer satisfaction has been done by many scholars, such as [3], [17], [19], [22], [20], who have stated that the company's image affects customer satisfaction.

A Master's in Management Science in Universitas Muhammadiyah Jember is a study program which is one of the pride products of the university. There are several universities in Jember Regency that have a master's degree in management study program, among others are Jember University and STIE Mandala Jember. Some of these universities that have master's degrees will likely become competitors for Universitas Muhammadiyah Jember in the future. This competition must be addressed by continuously improve education services and maintain the image of the institution in the community. In order to increase public interest in Universitas Muhammadiyah Jember, the university is demanded to keep improving the quality of education provided so as to provide satisfaction to customers. Satisfied customers will provide good information about the services they have received to other parties.

From the explanation in the background, the question in this research is how to increase the satisfaction and loyalty of graduate students in management program at Universitas Muhammadiyah Jember. While the purpose of this study was to determine the effect of service quality and institutional image on the satisfaction and loyalty of graduate students in Management at Universitas Muhammadiyah Jember.

\section{METHOD}

This research is a type of explanatory research. This study intends to explain the influence of variables through hypothesis testing and at the same time explain those variables. In accordance with the objectives of the research that is to analyze, test and confirm the effect of service quality and institutional image on student satisfaction and loyalty, the research will collect the necessary data, both primary and secondary data, carried out at Universitas Muhammadiyah Jember. The participants were students at Master's program in Management at Universitas Muhammadiyah Jember. Population is all objects that will be used as research objects [25]. The population in this study was students of the Master of Management Study 
using the reliability measurement facilities with Cronbach Alpha statistical tests [25]. Linear regression analysis is used to determine the effect of independent variables on the dependent variable [27]. With the following formulation: $\mathrm{Y} 1=\mathrm{a}+\mathrm{b} 1 \mathrm{X}+\mathrm{b} 2 \mathrm{X} 2+\mathrm{e}$ and $\mathrm{Y} 2=\mathrm{a}+\mathrm{b} 1 \mathrm{X} 1+\mathrm{b} 2 \mathrm{X} 2+$ $\mathrm{b} 3 \mathrm{Y} 1+\mathrm{e}$.

\section{RESULT}

\subsection{Descriptive Statistics Analysis Results}

The results showed that based on gender the number of male students was 31 students $(62 \%)$ and 29 female students $(38 \%)$.

\subsection{Validity and Reliability Test Results}

The results of the validity test and the reliability test can be seen in Table 1. The results of the validity test show that the value of Corrected Item-Total Correlation is above 0.05 , so that all variables used in the questionnaire are declared valid. Meanwhile, the reliability test results showed that the Cronbach alpha value of all variables used in this study had alpha values above 0.6 , so that all the variables were declared reliable. Measurements were made by measuring the correlation between the results of the answer to the question that is

Table 1 Validity test and reliability test results

\begin{tabular}{|lcccc|}
\hline & $\begin{array}{c}\text { Scale Mean if Item } \\
\text { Deleted }\end{array}$ & $\begin{array}{c}\text { Scale Variance if Item } \\
\text { Deleted }\end{array}$ & $\begin{array}{c}\text { Corrected Item-Total } \\
\text { Correlation }\end{array}$ & $\begin{array}{c}\text { Cronbach's Alpha if } \\
\text { Item Deleted }\end{array}$ \\
\hline X1 & 48.1600 & 33.117 & .644 & .788 \\
X2 & 50.5600 & 48.986 & .572 & .797 \\
Y1 & 48.0000 & 37.633 & .726 & .717 \\
\hline
\end{tabular}

\subsection{Results of Multiple Linear Regression Analysis}

The results of the linear regression analysis (Table II) with the dependent variable of student satisfaction indicate that the coefficient value for the service quality variable is
0.360 , whereas the coefficient value for the institutional image variable is 0.577 . T value for the service quality variable is 4.101 , while the calculated value for the institutional image variable is 3.996. The significance value for the service quality variable is 0.000 , while the significance value for the institutional image variable is 0.000 .

Table 2 Results of linear regression analysis with satisfaction as bound variables

\begin{tabular}{|cccc|}
\hline Model & Value b & Value t & Significance Value \\
\hline A constant & 2.728 & 1.166 & .250 \\
X1->Y1 & .360 & 4.101 & .000 \\
X2->Y1 & .577 & 3.996 & .000 \\
\hline
\end{tabular}

The results of linear regression analysis with the dependent variable of student loyalty (Table III) show that the coefficient value for the service quality variable is 0.246 , the coefficient value for the institutional image variable is 0.253 , and the coefficient value for the satisfaction variable is 0.114 . The calculated value for the service quality variable is 3,208 , and the calculated value for the institutional image variable is 2,014 . The t-count value for the student satisfaction variable is 1,044 . The significance value for the service quality variable is 0.002 , the significance value for the institutional image variable is 0.050 . The significance value for the variable student satisfaction is 0.302 . 
Table 3 Results of linear regression analysis with loyalty as a bound variable

\begin{tabular}{|cccc|}
\hline Model & Value b & Value t & Significance Value \\
\hline A constant & 1.541 & .865 & .392 \\
$\mathrm{X} 1->\mathrm{Y} 2$ & .246 & 3.208 & .002 \\
$\mathrm{X} 2->\mathrm{Y} 2$ & .253 & 2.014 & .050 \\
$\mathrm{Y} 1->\mathrm{Y} 2$ & .114 & 1.044 & .302 \\
\hline
\end{tabular}

\section{DISCUSSION}

\subsection{Effect of Service Quality on Student Satisfaction}

The results of statistical calculations show that the coefficient value for the variable service quality is 0.360 with a significance value of 0.00 . $T$ value for the service quality variable is 4.101 . From the results, the hypothesis there is an influence of service quality on student satisfaction - can be accepted. Quality of service is the nature of all products or services that can satisfy the needs of the community [2], and it can be in the form of services or products to be provided to customers or consumers [6]. Customer satisfaction is the level of one's feelings after comparing the performance with expectations [5]. Good service quality must be maintained by all service providers. Educational services provided by Universitas Muhammadiyah Jember are found able to increase the satisfaction of users of educational services, namely students. This good result must be maintained so that student satisfaction continues to increase. This research is in line with previous research that has been done a lot, such as [7], [9]-[12], [14], [17]-[20], [22]-[24] in which all conclude that good service quality can increase customer satisfaction, although Qomariah states that service quality has no impact on customer satisfaction.

\subsection{Effect of Institutional Image on Student Satisfaction}

The results of statistical calculations show that the coefficient value for the institutional image variable is 0.577 with a significance value of 0.00 . The $t$ value for the institutional image variable is 3,996 . In other words, the hypothesis, which states that there is an influence of the institutional image variable on student satisfaction, can be accepted. The company's image is a corporate identity that will be conveyed to the public [2]. Identity can be in the form of a logo, vision and mission of the company or the physical appearance of the company that will distinguish it from other companies such as uniforms, office buildings, transportation equipment, brochures, banners, the environment and so on [3]. The image of the institution must be maintained by all service providers because its good image will provide benefits to the public service users. The customers will tend to remember for long the satisfying service providers. Universitas Muhammadiyah Jember is one of private universities in the eastern region which contributes to the nation's intelligence. In the region, Universitas Muhammadiyah Jember has become one of the favorite higher educations. In this regard, Universitas
Muhammadiyah Jember is required to maintain its good name in order to survive the competition. Research on company image and customer satisfaction has been done by many previous scholars, such as [3], [17], [19], [20], [22] that have found the company's image affects customer satisfaction.

\subsection{Effect of Service Quality on Student Loyalty}

The results of statistical calculations show that the coefficient value for the variable service quality is 0.246 with a significance value of 0.002 . $T$ value for the service quality variable is 3,208 . The hypothesis stating that there is an influence of service quality on student loyalty; therefore, can be accepted. The quality of services provided to meet the needs and expectations of consumers and the accuracy in delivering it will cause a match between the expectations and acceptance of consumers when marketing a product brand. Universitas Muhammadiyah Jember has provided good services to users of its educational services. This is proven that the quality of service can increase student loyalty. Quality is a dynamic condition that affects products, services, people, processes and environments that meet or exceed expectations [28]. Studies by [7], [8], [10], [13], [14], state that the quality of service can increase customer loyalty, although other studies by [12], [15] deny.

\subsection{Effect of Institutional Image on Student Loyalty}

The results of statistical calculations show that the coefficient value for the institutional image variable is 0.253 with a significance value of 0.050 . $\mathrm{T}$ value for the institutional image variable is 2014. Based on these results, it can be stated that the hypothesis which states that there is an influence of the institution's image on student loyalty can be accepted. The company's image is a corporate identity that will be conveyed to the public [2]. Customer loyalty is an act of customer who provides information, recommends and tells good things from service providers [6]. Universitas Muhammadiyah Jember is a publicly recognized higher education institution, this is because its reputation already suits the people's expectations. This is proven that the image of an institution can increases student loyalty. The good name of the university must be maintained and improved so that people' trust in this educational institution and they will inform good things about this university. Research by [10], [16]-[18] argue that the company's image can make customers make repeat purchases and recommend to other customers. On the other hand, research by [3], [19]- 
Mediterranean Journal of Social Sciences, vol. 8, no. 51, pp. 129-135, 2018.

on the company's image of customer loyalty.

\subsection{Effect of Satisfaction on Student Loyalty}

The results of statistical calculations show that the coefficient value for the satisfaction variable is 0.114 with a significance value of 0.302 . T value for the institutional image variable is 2014. The results indicate that the hypothesis which states that there is an influence of satisfaction on student loyalty can be rejected. Customer satisfaction is a factor that can increase customer loyalty. Customer satisfaction is the level of one's feelings after comparing the performance witnessed with his expectations [5]. Customer loyalty is an act of customer repurchasing a product or service. Student satisfaction is the satisfied feeling of in the performance of education service he received which has exceeded the expectation. Students who are satisfied will provide positive information about educational institutions that have provided educational services. In this study, student satisfaction cannot increase student loyalty. With the results of this study, Universitas Muhammadiyah Jember must pay attention to student satisfaction so as to increase student loyalty.

\section{CONCLUSIONS AND RECOMMENDATIONS}

Service quality could affect student satisfaction. Students who get good education services will feel satisfied. Therefore, the university must continue to pay attention to the services provided to students. The institutional image variable influences student satisfaction. A good image of a higher education institution can actually increase student satisfaction. Thus, the educational institution must continuously improve its image in the community. Service quality variable affects student loyalty. Students who are satisfied with the education services they have received will provide good information and will recommend and invite the community to study at the university. Therefore, the university must continue to pay attention to the services provided to students. The institutional image variable influences student loyalty. A good image of an institution of higher education can apparently make active students provide good information and will recommend the university to the public, therefore maintaining and improving the image of the institution is not a question. Student satisfaction does not affect student loyalty. Students who are dissatisfied will not give good recommendations about the university to public. Therefore, Universitas Muhammadiyah Jember must continue to increase student satisfaction so that students provide good information about the university.

\section{REFERENCES}

[1] N. Qomariah, "Impact of Customer Value, Brand Image and Product Attributes to Satisfaction and Loyalty Tourism Visitors in Jember Regency,"
[2] P. Kotler, Manajemen Pemasaran. Jakarta: PT. Prenhalindo, 2007.

[3] N. Qomariah, "Pengaruh Kualitas Layanan dan Citra Institusi Terhadap Kepuasan dan Loyalitas Pelanggan," Jurnal Aplikasi Manajemen Universitas Brawijaya Malang, vol. 10, no. 1. pp. 177-187, 2012.

[4] F. Tjiptono, Service, Quality \& Satisfaction. Yogyakarta: Andi, 2007.

[5] P. Kotler and G. Amstrong, Prinsip-Prinsip Pemasaran. Jakarta: Penerbit Erlangga, 2008.

[6] N. Qomariah, Marketing Adactive Strategy. Jember: Cahaya Ilmu, 2016.

[7] A. Mulyawan and Rinawati, "Pengaruh Kualitas Layanan Akademik Terhadap Kepuasan Mahasiswa Serta Implikainya Pada Loyalitas Mahasiswa," vol. 10, no. 2, pp. 119-131, 2016.

[8] M. Maskur, N. Qomariah, and Nursaidah, "Analisis Pengaruh Kualitas Pelayanan, Harga, Dan Kepuasan Pelanggan Terhadap Loyalitas Pelanggan (Studi Kasus pada Bengkel Mobil Larasati Lumajang)," Jurnal Sains Manajemen \& Bisnis Indonesia, vol. VI, no. 2, pp. 212 221, 2016.

[9] F. Safitri, M. Rahayu, and N. K. Indrawati, "Pengaruh Kualitas Pelayanan dan Citra Perusahaan Terhadap Kepuasan Pelanggan dan Loyalitas Pelanggan Service Center [ Studi Pada Pelanggan Samsung Service Center di Kota Malang ]," Jurnal Ekonomi Bisnis, pp. 1-15, 2016.

[10] Sutrisno, D. Cahyono, and N. Qomariah, “Analisis Kualitas Pelayanan, Kepercayaan Serta Citra Koperasi Terhadap Kepuasan Dan Loyalitas Anggota,” Jurnal Sains Manajemen \& Bisnis Indonesia, vol. 7, no. 2, pp. 157-174, 2017.

[11] W. Rahman, "Pengaruh Kualitas Layanan Dan Citra Institusi Terhadap Kepuasan Mahasiswa Di Fakultas Ekonomi Universitas Muhammadiyah Luwuk," Jurnal Ilmiah Manajemen "E M O R," vol. 1, no. 2, p. 90, 2019.

[12] M. R. Afandi and T. Setyowati, "Dampak Kualitas Layanan Terhadap Kepuasan Pelanggan dan Loyalitas Pelanggan Pada Dira Cafe \& Pool Pontang Ambulu Jember,” vol. 4, no. 1, pp. 79-91, 2019.

[13] I. Sofiati, N. Qomariah, and H. Hermawan, "Dampak Kualitas Pelayanan Terhadap Loyalitas 
Konsumen," Jurnal Sains Manajemen \& Bisnis Indonesia, vol. 8, no. 2, pp. 244-259, 2018.

[14] R. I. Verriana and M. Y. Anshori, "Pengaruh Kualitas Layanan ( Service Quality ) Terhadap Loyalitas Melalui Kepuasan," Accounting and Managemen Journal, vol. 1, no. 1, pp. 63-79, 2017.

[15] E. D. K. Natalia, M. Setiawan, and A. Puspaningrum, "Pengaruh citra institusi dan kualitas layanan terhadap retensi melalui kepuasan mahasiswa (studi pada universitas ma chung di kota malang)," South East Asia Journal of Contemporary Business, Economics and Law, vol. 14, no. 3, pp. 13-21, 2017.

[16] S. A. Dewi, and Rulirianto, "Pelanggan Pt Buana Langgeng Jaya,” pp. 244-249, 2011.

[17] A. Djanas, "Kualitas Pelayanan dan Citra Perusahaan terhadap Kepuasan Serta dampaknya terhadap Loyalitas Wisatawan,” JSM (Jurnal Sains Manajemen) Program, vol. V, no. 2, pp. 184-192, 2016.

[18] A. Muzammil, M. Yunus, and N. Darsono, "Pengaruh Kualitas Pelayanan Dan Citra Perusahaan Terhadap Loyalitas Pelanggan Indihome Pt. Telkom Indonesia Di Banda Aceh Dengan Kepuasan Dan Kepercayaan Pelanggan Sebagai Variabel Mediasi," Jurnal Manajemen dan Inovasi, vol. 8, no. 3, pp. 104 133, 2017.

[19] F. I. Saputra, "Kualitas Layanan, Citra dan Pengaruhnya terhadap Loyalitas melalui Kepuasan Pelanggan ( Studi Pada PT Bank Bni 46 Sentra Kredit Kecil Surabaya )," Aplikasi Manajemen, vol. 11, no. 3, pp. 445-457, 2013.

[20] M. Mutmainnah, "Pengaruh Kualitas Layanan Dan Citra Perusahaan Terhadap Kepuasan Dan Loyalitas Nasabah," Jurnal Manajemen dan Pemasaran Jasa, vol. 10, no. 2, p. 201, 2018.
[21] I. K. Subagja and P. H. Susanto, "Pengaruh Kualitas Pelayanan, Kepuasan Nasabah Dan Citra Perusahaan Terhadap Loyalitas Nasabah Pt. Bank Central Asia Tbk Kantor Cabang Pondok Gede Plaza," Jurnal Manajemen Bisnis Krisnadwipayana, vol. 7, no. 1, pp. 69-84, 2019.

[22] Subagiyo, "Pengaruh Kualitas Pelayanan Akademik Dan Citra Institusi Terhadap Kepuasan Mahasiswa Lp3I Cilegon,” Jurnal Lentera Bisnis, vol. 4, no. 1, pp. 1-26, 2015.

[23] R. Anggriana, N. Qomariah, and B. Santoso, "Pengaruh Harga, Promosi, Kualitas Layanan Terhadap Kepuasan Pelanggan Jasa Ojek Online 'OM-JEK' Jember," Jurnal Sains Manajemen dan Bisnis Indonesia, vol. 7, no. 2, pp. 137-156, 2017.

[24] W. A. Setyawati, M. Rifai, and C. Sasmito, "Pengaruh Kualitas Pelayanan, Fasilitas, Harga dan Citra Institusi Terhadap Kepuasan Pasien.," Madani, Jurnal Politik dan Sosial kemasyarakatan, vol. 10, no. 2, pp. 50-63, 2018.

[25] I. Ghozali, Aplikasi Analisis Multivariate dengan Program SPSS. Semarang: Edisi Kelima Badan Penerbit Universitas Diponegoro, 2005.

[26] Sugiyono, Metode Penelitian Pendidikan Pendekatan Kuantitatif, Kualitatif, dan R\&D. Bandung: Alfabeta, 2013.

[27] A. Ferdinand, Metode Penelitian Manajemen:Pedoman Penelitian Untuk Penulisan Skripsi, Thesis, dan Disertasi Ilmu Manajemen. Semarang: Badan Penerbit Universitas Diponegoro, 2006.

[28] F. Tjiptono and G. Candra, Pemasaran Strategik. Yogyakarta: Andi, 2012. 